\title{
Thales, Anaximander and Anaximenes as pathfinders of modern science
}

\author{
Gabriel Ema Idang \\ Department of Philosophy, University of Uyo, Uyo, Akwa Ibom State, Nigeria
}

Email address:

gabrielidang@yahoo.com

\section{To cite this article:}

Gabriel Ema Idang. Thales, Anaximander and Anaximenes as Pathfinders of Modern Science. International Journal of Philosophy. Vol. 1, No. 4, 2013, pp. 57-65. doi: 10.11648/j.ijp.20130104.12

\begin{abstract}
Thales, Anaximander and Anaximenes, the first three earliest Ionian philosophers, flourished during the $6^{\text {th }}$ century B.C. and became active in Miletus which was an Ionian colony in Asia Minor. These philosophers are traditionally regarded as the first Greek philosophers on record. They attempted to explain the origin and structure of the world in a rational manner. Thus, they were concerned with cosmology, that is, the scientific (empirical) investigation of the world and its development. It is obvious that philosophy amongst them began as an act of independent thought; and they must have recognised that anything magical, religious or mythical differs from a natural, rational or scientific explanation. Available records show that in their philosophical speculations, they took into account only what falls under sense perception. This explains why they are known as natural philosophers who engaged themselves with the study of nature. They also inquired into what single material element constitutes the substratum (ultimate stuff) of the world. It is on the basis of the attempts to provide a complete, simple, unified explanation of the various phenomena of the world that the outline of the methods and concepts of modern empirical science were first drawn. The aim of this paper is to examine the contributions of these philosophers (Thales, Anaximander and Anaximenes) in order to justify them as exhibiting not only the temperament of science but also as constituting the foundation of modern science.
\end{abstract}

Keywords: Thales, Anaximander, Anaximenes, Cosmology, Water, Apeiron, Air, Element, Infinite, Invention, Experiment, Pathfinders, Science

\section{Introduction}

The seaport town of Miletus, located across the Aegean Sea from Athens, on the western shores of Ionia in Asia Minor (now Turkey) is regarded as the birth place of philosophy. This explains why the first philosophers of the western world are also called the Milesians or the Ionians. Thus, the early Ionian School is also known as the Milesian school. This school consists of Thales, Anaximander and Anaximenes who are traditionally regarded as the first Greek Philosophers. All of them where born in Miletus, a city in Ionia, east of Greece.

The Ionians, according to Owens (3) "sought their livelihood in seafaring and commerce....and they grew keenly interested in the stars by which they guided their ships and in pertinent meteorological data for both sailing and agriculture". The Ionians are said to have learnt so much from the Chaldeans and the Egyptians who were experts in geometry and astronomy. The Ionians used this knowledge to explain the nature and movement of the physical world in rational manner. The philosophical speculations by these philosophers, then, were mainly attempts to explain the origin and structure of the universe. Thus they were concerned with cosmology. And cosmology, as we understand, is the scientific study of the universe and its origin and development. The "cosmos" is the universe, seen as an ordered system.

All the three Ionians agreed that there must be some entity from which all other things comes into existence. They also believed this entity is some kind of material but each of them differed on the very nature of the material. They were, indeed, interested in questions concerning the primordial stuff of the universe or the basic constituents of the world. Philosophy among the Milesians (Ionians) began as an act of independent thought. They asked questions regarding what things really are, the processes of change in things, and so on. Their explanations were devoid of magic, religion, myths or even the activities of the gods. And it 
would seem they might have recognized that anything magical, religious or mythical differs from a rational or scientific explanation. Apart from the attempt to explain the nature of the physical world by reason alone, theses philosophers attempted to discover what everything comes from or what the basic constituents of the world is. Copleston (16) remarks that "science and thought, as distinct from mere practical calculations and astrological lore were the result of the Greek genius... they sought knowledge for its own sake and pursued knowledge in a scientific, free and unprejudiced spirit". Thus, the Greeks among the people of antiquity appeared to have succeeded in recognizing the difference between a purely rational explanation of things as distinct from myth or religion. Their philosophies, according to Owen (5), have "been regarded as a pursuit of physical science in a quite positivistic mentality ... or as a rational transcription of mythological traditions, or as an intellectual seeking of divine". Perhaps it is for these reasons that they have been called primitive scientists. From the very beginning, according to Stumpf (5), "Greek philosophy was an intellectual activity, for it was not a matter only of seeing or believing but of thinking, and philosophy meant thinking about basic questions in a mode of genuine and free inquiry". Onyewuenyi (167) writes that the pre-Socratic philosophers are known as natural philosophers who engaged themselves with the study of nature and the origin of the world; they inquired into what single material element constitutes the substratum of the world. Citing Paul Glenn, Onyewuenyi states that these philosophers... saw a world around them which evidently remained the same world, and yet was full of change, motion and of variety. There were dawns and sunsets, births and deaths, storms and calms, running streams and enduring, moving planets, solid earth and the ever restless seas. There were various kinds of things in the world --- minerals, plants, brutes, men. Now the Ionians felt that, back of all changes and varieties in the world, there must be some one thing which is the fundamental material out of which all things are made, some "world-stuff" of which different things are the variant and manifestations (167).

Onyewuenyi further observes that the Greek philosophers tried to answer this question and each of them named the "world stuff" in his own way. At this point, it is germane to look at the concept of philosophy.

\section{What Is Philosophy?}

The question: "what is philosophy?" is, in fact, a philosophical problem. This is because philosophy as a term is not amenable to any uniform definition owing to the fact that different philosophers define it differently depending on the point of view they adopt. Different definitions are given to philosophy because the area of specialty of a person together with his conception of reality, intellectual background and so on, all come to play in the definition. While it may not be accepted that these definitions capture the whole essence of philosophy, they cannot be totally discarded since they, at least in part, show what philosophy is or what philosophers do. Aristotle, the ancient Greek philosopher was right to have conceived of wisdom as a proverbial door which no archer completely misses (a point) in an attempt to hit a mark.

Etymologically, philosophy is derived from two Greek words "philos" and "sophia" meaning "love" and "wisdom" respectively. Thus, the root meaning of philosophy is "love of wisdom". The Greeks themselves regarded any person who pursued knowledge in any area as a philosopher, lover of wisdom. The Pythagoreans, a group of ancient philosophers, divided the human race into three classes namely: the lovers of gain, the lovers of honour, and the lovers of wisdom. The third class, the lovers of wisdom, is like spectators who observe everything around them and contemplate in an effort to grasp a wider, better understanding. The Pythagoreans regarded the philosopher as a seeker after truth and, for them, the life of a philosopher is the highest of all lives (Owens, 32).

Even though there is a general understanding that philosophy means "love of wisdom", it is not surprising, given the controversial nature of philosophical questions that not all philosophers agree that this definition is still valid today. It was, however, accepted as adequate in the ancient times when every intellectual inquiry was called "philosophy". But with the emergence of the specialized disciplines which also claim to be love of wisdom in their own areas, the definition no longer serves to distinguish philosophy from other disciplines. Of course, even philosophers who agree that philosophy is the love of wisdom would almost certainly have different views about what "wisdom" is and what it means to "love" wisdom. Philosophers never rest content with their penchant for conceptual analysis.

Ancient Greek philosophers, such as Plato and Aristotle, did not trouble themselves too much in describing what it was they were trying to do. A philosopher, as far as they were concerned, was someone who was interested in the pursuit of reality, knowledge and truth in all spheres of human existence. Thus, the search for reality, knowledge and truth also constitute what is called philosophy. These philosophers asked questions and supplied answers. The answers they gave are still energetically disputed today even after centuries of debate. This means that philosophical problems, like the definition of philosophy itself, are perennial problems. The seeming lack of definitive answers in philosophy may appear quite frustrating until we come to see that the value of philosophizing lies not so much in the theories it produces as in the very activity of seeking wisdom. Bertrand Russell, the eminent British philosopher writes that philosophy should be studied not for the sake of definitive answers to its questions... but rather for the sake of the questions themselves because these questions enlarge our conception of what is possible, enrich our intellectual imagination and diminish the dogmatic assurance which closes the mind against speculation. (161) 
To engage in philosophy is to deepen our understanding of fundamental issues and enrich our lives. Philosophy helps people decide wisely and act consistently and to discover values and the meaning of things. Philosophy, then, enables people to decide questions of truth and falsity, of beauty and ugliness and of right and wrong. Before we draw the curtain here, we state the following objectives of philosophy as outlined by Etuk:

(a) To train people to reason critically, correctly and constructively.

(b) To give people some insight into the moral, aesthetic and religious values of their culture as well as those of other cultures; so as to enable them to make wise choices and contributions.

(c) To prepare people's minds to enable them make wise political choice when it comes to their construction of their societies.

(d) To equip people with the kind of attitude and judgment that will enable them live constructive and useful lives in societies of free people.

(e) To provide people with the intellectual background necessary for success in the business and professional areas of life (cited in The Uses of Philosophy, 3).

\section{Brief Survey of the History of Philosophy}

History of philosophy is an account or a narration of remarkable and even surprising developments in man's intellectual life from one time to another. Frolov (321) says history of philosophy is a "science which studies the origin and progressive development of philosophy, the laws and phase of this development, and the struggle of philosophical schools and trends". We are necessarily limited by the scope of this paper to attempt an elaborate survey but we shall try to capture, in short details, the basic trends in a particular epoch which, of course, has its peculiar, distinctive spirit and temper. However, we note that before the ancient period of philosophy, the thoughts and contemplation of the universe were steeped in mythology and superstition. Such thoughts and contemplation, unarguably, could not pass for the philosophical.

Now, the ancient period which witnessed a paradigm shift from mythology and superstition to rational speculation/reflective and empirical inquiry, started with the Pre-Socratic schools namely: the Early Ionan school, the Pythagorean school, the Eleatic school, the Later Ionian school, the Sophists, the Atomists and then by the Socratic and the Post-Socratic schools. Ancient philosophers from Thales onward speculated and attempted to explain the origin and structure of the universe, and were chiefly concerned with cosmological studies with the exception of the Sophists (the sceptics) whose main interest was man. However, some philosophers like Socrates were interested in human existence, morality and how an ideal society should be, amongst other things.

The medieval period was dominated by the application of religious interpretations to philosophical problems. According to Udoidem (51) 'one of the distinguishing marks of the philosophers of this period was a definite belief in divine revelation. The revealed message was accepted on faith and regarded as an unquestioned source of truth". This period was the era of Christian thinkers who were both philosophers and theologians. They tried to explain reality as well as answer fundamental philosophical questions such as the ones relating to the existence of God, the problem of evil, man's freedom, the meaning of right and wrong, the purpose of life, and so on. St. Anselm, St. Thomas Aquinas, John Scotus Eriugena, Avicenna, St. Bonaventure and Averroes are some notable philosophers of the medieval period. Although religion dominated this era, we could spot scientific elements in some of their thoughts and discoveries. For instance, St. Thomas Aquinas relied on empirical evidence to support his cosmological argument for God's existence, that is, the appeal to observable facts in the physical world just like most of his ancient counterparts. He considered philosophy and science as the handmaids of theology. Significant progress was recorded in applied science such as the making of paper, glass, gun-powder, clocks and so on. Roger Bacon (1214 1294) carried out many experiments in optics and alchemy, and considered experiment as the real test of truth. Johan Gutenberg (1397 - 1468) developed the method of printing which enhanced literacy and mass production of books especially the Bible. This period gave birth to another period commonly called "modern".

Modern period in philosophy was essentially characterized by two controversial but complementary tendencies namely: empiricism and rationalism. Empiricism is a position in philosophy which says that all knowledge come from experience while rationalism maintains that reason is the fundamental means of knowing reality. Empiricism adopted the method of empirical (natural) science while rationalism adopted the method of mathematics. Modern period started with the Renaissance a period of intellectual reawakening, discovery and emancipation. Modern science gradually emerged during the renaissance; and emphasis shifted from mere reading of traditional texts to observation and formulation of hypothesis. In order to enhance the exactness of observation, scientific instruments were invented and used, and quite a good number of discoveries and inventions were made. For example, the invention of paintings by Giotto (1276-1337), telescope by Tippersshey in 1608 though it was Galileo who first made use of it; air pump by Guerike (1602-1686); circulation of blood by Harvey (1578-1657) to mention but a few. Stumpf (225) observes that "the method of observation and mathematical calculation now became the hallmarks of modern science". Let us look at individual philosopher's contribution to philosophy beginning with Thales. 


\section{Thales $(624-547 \mathrm{BC})$}

Most historical records show that Thales lived between 624 and 547 BC. He was the founder and leading member of the Ionian (Milesian) School of ancient thinkers. Copleston (17) writes that "it was at Miletus that Thales, the reputedly earliest Ionian philosopher, flourished". Herodotus, the Greek historian, is widely acclaimed to have been the earliest source of information about Thales but much of what is known of him also comes from writings of other philosophers like Aristotle. Thales is said to have descended from Phoenicians who had settled in Miletus. Thales however has been regarded by many as the father of Western philosophy and the first philosopher on record in the West. According to Sullivan (9), Thales "was one of the legendary seven wise men of Ancient Greece and he knew the famed lore of the Chaldeans". (The Chaldeans knew how the heavenly bodies move). Instead of telling fortunes by the position of the planets, Thales used this knowledge to explain the nature and movement of the physical world in a rational manner. For Omoregbe (3), "Thales had a very curious mind which impelled him to seek a rational explanation for the nature of the cosmos". Apart from the attempt to explain the nature of the physical world by reason alone, Thales also attempted to discover what everything comes from or what the basic constituents of the world is.

Thales was so interested in the heavens to the extent that while gazing upward and scanning the stars, he fell into a well. He became so famous for his shrewdness and theoretical wisdom by making important discoveries whose true origin were not known then and in some cases are still obscure. For instance, the most spectacular of these achievements was his alleged prediction of a total solar eclipse which actually occurred on May 28,585 BC. At that time, the information needed to foresee such an event may not have been possessed by any known person. Other achievements ascribed to Thales, according to Copleston (20) "are the construction of an almanac and introduction of Phoenician practice of steering a ship's course by the Little Bear".

Thales, according to Uduigwomen (21), constructed an instrument for measuring the distance of a ship sighted at sea, and in the field of astronomy and navigation, he discovered the constellation little Bear which could be used for determining the direction of the north by sailors. Such achievements are very impressive, and perhaps it might be on the basis of this that Ozumba (52) sees Thales as "the originator of instrumentalism". Thales also solved the problem of crossing the wide Halys River by the use of a dam which created two channels. Thales also tried to subject his entire hypothesis to rigorous testing, and he employed scientific method of testing in validating his claims. For instance whenever the shadow of a person equates his height, Thales would recommend that we can measure the height of the Pyramid by measuring its shadow. Copleston (22) sees in Thales "the mixture of a philosopher and practical scientist."

Thales is also credited with the statement that everything is full of gods. This opinion might have been derived from those who hold that the soul pervades the entire universe. Thales possessed great power of imagination by assuming that magnet has soul. He argued that soul causes motion, and magnet, because it can move iron, has soul. Such assumption which appears to be unsatisfactory can be seen as an act of imagination. Rosen (396) observes that "with regards to Thales conception of soul, Aristotle remarked that on the basis of what people remember, Thales apparently assumed that soul causes motion, if he really said that magnet has a soul since it attracts iron". And for Owens (8), "certain thinkers say that soul is intermingled in the whole universe, and it is perhaps for that reason that Thales came to the opinion that all things are full of gods."

Thales sought a primordial principle in the diversity of things and regarded it as a corporeal substance perceptible by the senses. According to Onyewuenyi (168), "Thales taught that water was the fundamental material out of which all things were made and the last into which they are resolved". In other words, water was the original material from which everything else is produced or the primary elements of all things. This is usually regarded as the oldest traditional explanation which says that what held the earth up was that it rested on water. According to Robinson (292), "Aristotle tells us that Thales made the earth rest on water and that he made water the "element" and "first principle" of existing things". Robinson goes ahead to state that for Thales, the earth is supported by water and sails like a ship; and when it is said to quake, it is pitching because of the movement of water. Thales' conception of water as the fundamental principle of the universe seems to have been based on the observations that the nourishment of all things was moist and that heat itself arises from this source and is kept alive by it. Ozumba is satisfied that through careful and meticulous observation, Thales concluded that water is the primary substance of the world with the following reasons: that water pervades all things, everything consists of water, water is the source of plant and animal life, water is capable of mutation giving rise to the three types of substance, that is, gaseous, solid and liquid, water is unlimited and contains the finite universe, the earth itself is borne of water, the seed of all the things have a moist nature and water is the origin of the nature of moist things. Nourishment, and living things come from water (51).

Thales is believed to have derived this notion from the fact that the seeds of all things have a moist nature. Because of that, water is seen as the origin of the nature of most things. (Idang, Ancient, 47). As Copleston (23) observes, "it is clear that the phenomenon of evaporation suggests that water may become mist or air, while the phenomenon of freezing might suggest that if the process were carried further, water could become earth". Russell (45) writes that "the statement that everything is made of water is to be regarded as a scientific hypothesis, and by no means a foolish one". Russell tells us that the received view 
in the recent past is that everything is made of hydrogen, which is two thirds $(2 / 3)$ of water. Rosen suspects that the primacy of water may have been imported by Thales from the Egyptians who express this idea in mythical form.

Thales demonstrated also that philosophers can become rich if they want to. According to Ozumba (50) "Aristotle records of Thales that he was once reviled for being so poor. Thales simply used his astronomical knowledge to predict that there will be a bumper harvest of olives. He bought up all the Olives Presses, and during the time of scarcity he enjoyed a monopolistic sale of olives and became rich..." We can see, from available facts, that Thales was a geometer, astronomer, an engineer and, indeed, a natural philosopher.

\section{Anaxmander (610-546BC)}

From Miletus, Anaximander, the son of Praxiades, was known in Greek tradition as the pupil, associate and successor of Thales. It is believed that he took part in the founding of Apollonia on the Black Sea, and he is said to have travelled to Sparta. Unlike his master Thales, Anaximander is said to have written a book on his philosophical teachings titled ON NATURE. He was concerned with the origin of things, and he attempted to explain the origins of the universe through his theory of the aperion. According to Copleston (24) "Anaximander busied himself with practical scientific pursuits, and is credited with having constructed a map probably for the Milesian sailors on the Black Sea".

Like Thales, Anaximander agreed that there must be some entity from which everything else comes into existence. But he differed from Thales by postulating that the fundamental material which explains the origin of all things is a neutral element different from all the known elements. Anaximander called this element the "aperion" which is described as indefinite, infinite, or unlimited; the aperion is deathless, imperishable, everlasting and ageless. Put in another way, this element is infinite, unlimited, eternal, boundless and indeterminate. Anaximander's choice of the "aperion" is based on his conviction that all the elements we know are always in conflict with each other and if any of those elements were the original material, it will subdue and even submerge the others.

Anaximander saw the conflict between the different elements as an instance of injustice in nature because conflict itself becomes the means of one element invading the other. Individual existence, for Anaximander, commits injustice against each other simply by coming into being and thereby lessening each other's viability. But Omoregbe (5) notes that Anaximander actually maintained that "there is a cosmic law of justice which establishes order and makes everything go back into that from which it came".

Anaximander also maintained that there are many worlds and that the one we inhabit is not the only world. He saw the earth like a cylinder which floats at the centre of the universe. Therefore the earth cannot fall in one direction of another. The earth, Anaximander believed, was originally covered with water and became dried in part, and man is said to have sprang from aquatic forms which moved into the drier part and adapted themselves to the new conditions. Anaximander, it would seem, was the first Greek to teach the doctrine of organic evolution. He is also reputed to have been the first Greek philosopher to draw a map of the inhabited earth. Ross (170) sees him "as a boldly imaginative thinker who broke with the mythological explanations of the universe found in the Greek poetic and religious tradition in favour of explanations based on logical premises".

\section{Anaximenes (588 -526BC)}

Anaximenes is said to have lived between 588 and 526 BC. He was the last of the first three Greek philosophers from Miletus. The details of his life are almost totally unknown, and his doctrine seems to be a decided retrogression from the stage reached by Anaximander. But Anaximenes follows Thales in assigning a determinate element as the basic substance out of which all other things arise. As opposed to Thales' "water" and Anaximander's "aperion", Anaximenes postulated "air" as the determinate element or the origin of all things. Copleston (26) assumes that Anaximenes choice of air "may have been suggested to him by the fact of breathing, for man lives so long as he breathes, and it might easily appear that air is the principle of life".

Anaximenes tried to explain the creation of all forms of matter through the mechanism of condensation and rarefaction of air which seems to be composed of discrete particles. Anaximenes describes air as being invisible when evenly distributed but by the process of condensation it becomes visible as cloud, water and finally earth and stone. Rarefaction, on the other hand, causes air to expand and become hot and then turn to fire. The notion of condensation and rarefaction, as we could see, is being used to explain how concrete objects are formed from the primitive element. In other words, when air becomes rarefied, it becomes warmer and thus gives rise to fire. When it becomes condensed, it grows colder and tends toward wind, cloud, water, earth, and other solid objects.

Anaximenes, according to Ross (171) also "assumed the air to be in a state of perpetual motion. This provided an explanation for the changes of density which produced the infinite number of worlds that came into being and then disappeared, being absorbed into infinite air". For Cavendish (3) "Anaximenes explained various meteorological phenomena such as hail, rain, snow, thunder, and lightening. Worlds come into being and pass away in the course of "cycles of time". Anaximenes is said to have equated the air that supports the universe with human breath which is identified with the soul. This implies that air possesses life, and this idea is compatible with contemporary belief in the identification of air with life. Cavendish (3) claims that one sentence of Anaximenes 
survives namely: "as our soul, being air, holds us together, so do breathe and air surround the whole universe". In his cosmology, Anaximenes taught that the earth is flat and floats on air just like other galaxies. He described the universe not as a complete sphere but as a hemispherical, with the stars passing around the earth.

Our attempt to explore the philosophical contributions of Thales, Anaximender and Anaximenes is necessarily limited by the fact that little or nothing about their writing seems to survive. What may be gleaned from the writings of others is too little to permit an elaborate work on these philosophers. At this juncture, it is germane to look at the idea of science in order to ascertain the view that these philosophers are the Pathfinders of modern science.

\section{Some Conceptions of Science}

The question "what is science?" seems to be really much too grand a question to be answered in a few words because conventional definitions of science tend to emphasize quite different features, depending upon the point of view. And since each of the metascientific discipline seems to concentrate upon a different aspect of the subject, it is ideal to look at the different conceptions of science.

The term "science" comes from the Latin word "scientia" which means "knowledge". Science as knowledge, then, must cover a wide range of human enterprise such that any acceptable definition must take into consideration the various aspects of it because there are many types and classifications of the term "science". Literally, science means knowledge arranged in an organized or orderly manner, especially knowledge derived from experience, observation and experimentation. This explains why it is often said that scientific knowledge is proven knowledge. Thus, science for Uduigwomen (52), "is based on what we can see, touch, taste, hear, and smell'. For that reason, personal opinions, prejudices or preferences, superstitions and speculative imaginings have no place within the exclusive province of science.

Now, if science is a means of solving problem, then such conception emphasizes its instrumental aspect, and science is thus viewed as closely connected with technology. And if science is conceived as an organized knowledge, such conception tends to emphasize its archival aspect. Therefore information about natural phenomena is acquired through research and organised into coherent theoretical schemes. Ziman (1) suggests that "we may follow an old philosophical tradition by emphasizing methodological aspect of science". This means that procedures such as observation, experimentation and theorizing are considered elements of a special method for obtaining reliable information about the natural world. On this view, science is regarded as essentially objective, and hence transcending all other considerations.

Science can be seen as a discipline but not all disciplines are sciences. Science seen as a discipline implies, as Ratzsch (14) has noted, "that it has characteristic methods, addresses specific types of questions, advances specific types of answers and carries with it a fund of result as well as a characteristic of set of presuppositions". Thus natural science tries to provide natural explanation in terms of what Ratzsch calls "God's specific activity, purposes or plans". In common usage, science denotes only the aspect of learning, which represents a systematic accumulation of knowledge pertaining to nature of the operation of general laws in which sense the term can be used as an abbreviation for natural science. As a matter of fact, so much can be expressed about science from each of these and from other aspects. It is a truism that science is all these and more. We can conclude that science is a product of research; it does employ characteristic methods; it is a body of organised knowledge and a means of solving problems. Science can also be seen as a social institution, an educational theme, a cultural resource and, of course, a major factor in the affairs of man. Some of the aims of science include description, explanation and prediction; and what the scientists are seeking are descriptions, explanations and predictions which are as adequate and accurate as possible in the given context of scientific research.

Now, modern science is believed to have stated with the movement known as the renaissance. Renaissance, according to Frolov (358), is "a term denoting the sociological and philosophical doctrines that developed in Europe (primarily in Italy) at the time of the decline of feudalism and the emergence of bourgeois society". The spirit of the renaissance gave rise to new learning which led to important new discoveries and inventions and a good number of them were made, for instance, the discovery of the planets. Nicolas Copernicus (1473-1543) developed the heliocentric theory that the sun is the centre of the universe and the earth and other planets move around it.

One major but important result of the renaissance was the separation of philosophy as an independent secular science. By secular science is meant the discipline whose peculiar task was held to be the knowledge of nature. Thus, philosophy was conceived as natural science. The significant feature of the renaissance included the development of the new method of natural science, which was attributed to scientists from Kepler and Galileo down to Newton. It also included the development of modern philosophy as a result of the conscious application of both scientific and mathematical methods in reflection. This methodical reflection provided fresh material and hence new point of view for the treatment of practical as well as theoretical problems concerning nature. (Idang, History of Philosophy, 66)

\section{Scientific Development among the Greeks}

Prior to Greek civilization, the Babylonians, the Egyptians and the Persians were already engaged in the studies of astronomy, astrology and mathematics. These 
had great influence on the Greeks who utilized and applied this knowledge in quite a number of ways. The first set of philosophers who demonstrated this influence were Thales, Anaximander and Anaximenes followed by Pythagoras, Heraclitus, Empedocles, Anaxagoras, Leucippus, Democritus, Aristotle and so on. These philosophers were regarded as scientists even though they may not have been as sophisticated as present day scientists. They exhibited the scientific attitude of patient observation of facts as well as philosophical attitude of questioning everything that perplexed them with a view to providing answers and possible explanations for them. Appearances and movements of heavenly bodies, the seas, lands, animals, plants, the phenomenon of life and death among other things perplexed them. Interestingly, they formulated concepts and tried to subject their hypothesis to rigorous testing though without the use of scientific tools as in the contemporary world.

In order to express their thoughts, Thales, for instance, invented (formulated) the concept known as "element"; Anaximander formulated "infinite"; Leucippus and Democritus coined the concept known as "atom"; Plato formulated "ideas" while Aristotle formulated "cause", to mention but a few. These philosophers were preoccupied above all other things by the desire for knowledge in the sense of explaining and thereby mastering the processes of nature and from this desire science and philosophy emerged. Mbat (104), on this view, writes that "philosophy was meant as a pursuit of all knowledge and included facts and data as are exemplified in the Babylonian and Egyptian astronomical and mathematical sciences from which the Greeks borrowed". In general, the ancient Greek schools tried to combine their theorizing about the universe with knowing some facts and this made their scholarship distinct, unique and fruitful in the development of science. In history, Greek philosophy presented the first beginning of what is known as science. In support of this position, Hutten (42) writes that "it is the discovery of Greek learning during the renaissance that we generally recognize as the startingpoint of science in the modern sense of the word". In addition, the classical problem of philosophy were originally of scientific character, or they arose from the limited, confused and mistaken attempts of the Greeks to come to terms with nature (Hutten, 45).

\section{The Scientificity of the Philosophy of the Early Greek Philosophers: An Evaluation}

The fundamental question is: how scientific were thoughts of Thales, Anaximander and Anaximenes? The readiest answer which may be provided is that these philosophers, in their philosophical speculations, took into account only those things that fall under sense perception, and they attempted to explain as well as provide answers to fundamental questions in a rational manner. Shand (2) declares that "the importance of the pre-Socratic philosophers particularly the earlier ones is to be found in their speculations in physics, the study of nature for it is among these early tentative attempts to provide a complete, simple, unified explanations of the various phenomena of the world, or universe, that the outline of the methods and concepts of modern empirical science were first drawn". Now, concerning the basic constituents of the world, Thales, Anaximander and Anaximenes postulated water, the apeiron and air respectively. Such postulations raise some difficulties about the origin of man and the world. Certain scientific theories, such as evolutionism, hold that things gradually evolved from a single-celled organism some billion years ago. The failure to account for the original primordial stuff, how the original element changed from a homogenous to a moving one, and from plant to animal and then to human generates problem. Emanationism and creationism are other rival theories which point to God as the source and creator of all things.

However, some scholars have criticised these philosophers on the scientific nature of their speculations. For example, Furley and Allen raise doubt about the experimental aspects of what is credited to these philosophers thus:

...they were, moreover, equally dogmatic on questions beyond the reach of observation, let alone experiment. They announced, with the same assurance, that the ultimate constituents of material things were water or air... and they described the process whereby an ordered world had risen out of these elements. None of them had witnessed the process, or had the faintest conception of any method for isolating an element. Yet they narrate the history of the world from such beginning as if it happened before their eyes (30).

Furley and Allen also describe the main feature of Anaximenes's system as a reduction of differences of temperature to differences of density: the hotter, the thinner, the colder, the denser. Water is the only substance which can easily be seen passing into vapour when heated and becoming solid when cooled. When water turns to steam, it expands; when chilled into ice, it ought to contract into a smaller volume. But the question is: Does it contract? Furley and Allen submit that if Anaximenes had put a jar of water outside on a frosty night, he might observe that the water did not shrink when it turned into ice, but on the contrary, splits the jar. On this note, Furley and Allen conclude that Anaximenes never had recourse to this simple experiment.

The above submission notwithstanding, when we examine the contributions and achievements of these philosophers, we would accord them due credit as first natural philosophers on record. We subscribe to and agree with Cavendish (4) on the view that "though they were not scientist, they showed a common-sense and unmystical attitude which is a part of the scientific temper." The questions they set out to answer were scientific questions only in the vaguest sense of the term. Although the science 
and philosophy of these Greek philosophers appear to be crude, we would like to conclude that they were such as to stimulate both thought and observation.

The views of the Ionians were both scientific and philosophical. The Ionian systems were based on observation, and hypothesis were framed by rational inference and observed facts which were checked by experiment. The Ionians systems were philosophical because they were concerned with the search for ultimate reality and truth about the world we inhabit. They were interested in knowing the primordial stuff of the universe or the basic constituents of the world and they tried to find out how phenomena in the world work. After all, "the purpose of science is to obtain knowledge of facts, laws and process of nature". (Idang, Philosophy: Outline, 113). And scientists are interested in questions such as "what is ' $X$ ' made of? What causes ' $Y$ '? These philosophers were busy doing that; they also applied reason in arriving at conclusions.

\section{Concluding Remarks}

Thales, Anaximander and Anaximenes exhibited reasonable knowledge about natural philosophy, and they knew a great deal about their environment. The pursuit of knowledge in an empirical, free and unprejudiced manner came to its fruition right from the time of Thales. The invention (formulation) of concepts used in the explanation of phenomena as we have stated before helps in eliminating pseudo or misleading scientific hypothesis, law or theory. Observation, explanation and experiment, among other things, have continued to remain very essential and basic ideals of science from its cradle. Lindberg, in his The Beginnings of Western Science, writes that: we would do well to remember that natural philosophy was the intellectual venture to which so important a scientific luminary as Isaac Newton (late seventeenth century) assigned his own work, entitling his great book on mechanics and gravitational theory The Mathematical Principles of Natural Philosophy. Natural philosophy, the investigation of nature, was conceived by Newton, as by his ancient ... predecessors, to be an integral part of the philosophical exploration of the total reality that humans confront. (4)

These philosophers, as we can see, were the initiators of a serious, critical (rational) inquiry into the nature of the world, and such has stretched from their time to our present moment. They contributed significantly to the development of science, and we can easily find traits of scientific ingenuity in them. Thales, Anaximander and Anaximenes are philosophers with scientific temper. The unmistakable conclusion is that they actually laid the foundation for science, and as such they are qualified to be designated as Pathfinders of Modern Science even though their methods may have been in a rudimentary manner.

\section{References}

[1] Cavendish, A. P. "Early Greek Philosophy" in D. J. O'Connor (Ed.). A Critical History of Western Philosophy. New York: The Free Press, 1964.

[2] Copleston, F. A History of PhilosophyVol. 1. New York: Image Books, 1985.

[3] Etuk, U. "Uses of Philosophy" in U.Etuk (Ed.). An Invitation to Philosophy Vol. 3. Uyo: Robertminder International Ltd., 2009.

[4] Frolov, I. (Ed.) Dictionary of Philosophy. Moscow: Progress Publishers, 1984.

[5] Furley, D. J. and R. E. Allen. Studies in Pre-Socratic Philosophy. Vol. 1. London: Routledge and Kegan Paul, 1970.

[6] Hutten, E. The Origin of Science: An Inquiry into the Foundation of Western Thought. London: George Allen, 1962.

[7] Idang, G. E. Ancient Philosophy: A Text for Beginners. Uyo: Inela Ventures \& Publishers, 2009.

[8] Idang, G. E. "History of Philosophy: An Introduction" in U. Etuk (Ed.). An Invitation to Philosophy Vol. 2. Lagos: MacGrace Academic Resource Publishers, 2006.

[9] Idang, G. E. Philosophy: An Outline for Beginners. Uyo: Hearty-Deal Printers, 2008.

[10] Lindberg, D. C. The Beginnings of Western Science. Chicago: The University of Chicago Press, 1992.

[11] Mbat, J. P. "An Introduction to the History and Philosophy of Science" in U. Etuk (Ed.). An Invitation to Philosophy Vol. 2. Lagos: MacGrace Academic Resource Publishers, 2006.

[12] Moore, B. N. and K. Bruder. Philosophy: The Power of Ideas. California: Mayfield Publishing Co., 1999.

[13] Omoregbe, J. I. A Simplified History of Western Philosophy, Vol. One: Ancient and Medieval Philosophy. Lagos: Joja Educational Research and Publishers, 1991.

[14] Onyewuenyi, I. C. The African Origin of Greek Philosophy: An Exercise in Afrocentrism. Nsukka: University of Nigeria Press, 1993.

[15] Ozumba, G. O. "Ancient Period in Philosophy" in I. I. Asouzu (ed.). Philosophy and Logic Today. Calabar: The Africa Pacific and Allied Press, 2002.

[16] Ratzsch, D. Philosophy of Science: The Natural Science in Christian Perspective. Illinois: Inter-Varsity Press, 1986

[17] Robinson, J. M. An Introduction to Early Greek Philosophy. New York: Houghton Mufflin, 1968.

[18] Rosen, E. "Thales" in The McGraw-Hill Encyclopaedia of World Biography. New York: McGraw-Hill Books, 1973.

[19] Ross, D. A. "Anaximenes" in The McGraw-Hill Encyclopaedia of World Biography. New York: McGrawHill Books, 1973.

[20] Russell, B. A History of Western Philosophy. London: Unwin, 1979. 
[21] Shand, J. Philosophy and Philosophers: An Introduction to Western Philosophy. London: UCL Press, 1991.

[22] Stumpf, S. E. Philosophy: History and Problems. New York: McGraw-Hill, 1979.

[23] Udoidem, S. I. Understanding Philosophy. Lagos: African Heritage Research and Publishers, 1991.
[24] Uduigwomwen, A. F. History and Philosophy of Science. Aba: A. A. U. Industries, 1996.

[25] Ziman, J. An Introduction to Science Studies: The Philosophical and Social Aspects of Science and Technology. New York: Cambridge University Press, 1988. 